ORIGINAL RESEARCH

\title{
Parental Challenges in Promoting the Well-being of Talented Youths in Indonesia: A Phenomenological Study
}

\author{
Nur Setiawati Dewi ${ }^{1}$, Piyanuch Jittanoon², Wantanee Wiroonpanich² \\ ${ }^{1}$ Department of Nursing, Faculty of Medicine, Universitas Diponegoro, Indonesia \\ ${ }^{2}$ Faculty of Nursing, Prince of Songkla University, Thailand
}

\begin{tabular}{l}
\hline Article Info \\
\hline \\
Article History: \\
Received: 18 November 2020 \\
Revised: 12 July 2021 \\
Accepted: 9 August 2021 \\
Online: 27 August 2021 \\
Keywords: \\
Indonesia; Javanese Muslims; \\
parenting challenges; talented \\
youth; well-being \\
Corresponding Author: \\
Nur Setiawati Dewi \\
Department of Nursing, Faculty of \\
Medicine, Universitas Diponegoro, \\
Indonesia \\
Email: \\
nurse.tiawatidewi@fk.undip.ac.id
\end{tabular}

\begin{abstract}
Background: Parenting talented youths is a challenging task since most talented youths experience role complexities in their lives. Thus, raising talented youths can lead to increased challenges of parenting.

Purpose: This study aimed to explore the challenges faced by Javanese Muslim parents in promoting the well-being of talented youths.

Methods: A descriptive phenomenological approach was chosen to guide this study. Thirteen Javanese Muslim parents of talented youth (nine men and three women) were recruited using snowball and purposive sampling techniques. The data were obtained by conducting semi-structured interviews and field notes. The collected data were transcribed using verbatim transcription and analyzed using Giorgi's method of analysis.

Results: Three themes were found after data analysis, i.e., challenges coming from the youths, challenges from the community, and the existence of financial constraints in the family. Challenges coming from the youth were related to the oppositional behavior of talented youths and difficulties in managing children's activities as students and as talented youths. Challenges from the community included low commitment and belittling behavior from teachers or lecturers, ridicule from their neighbors, gender-based discrimination, and the absence of support from the organization. Another theme was related to financial constraints in the family which made it difficult for parents to finance their youth's education and talent activities.

Conclusion: Identifying the actual problems experienced by the talented youths' parents could help nurses develop appropriate family programs, consider, and incorporate holistic aspects into the programs to obtain optimal results.
\end{abstract}

How to cite: Dewi, N. S., Jittanoon, P., \& Wiroonpanich, W. (2021). Parental challenges in promoting the well-being of talented youths in Indonesia: A phenomenological study. Nurse Media Journal of Nursing, 11(2), $244-254$. https://doi.org/10.14710/nmjn.v11i2 34258

\section{Introduction}

Talented youths are people who have extraordinary abilities in at least one human activity, which places them in the top 10\% of their peer group with similar expertise in that field (Dewi et al., 2021). Approximately 2-5\% of Indonesian children are identified as talented youths (Dewi et al., 2021; Janah et al., 2018).

To be parents of talented youth is not an easy task (Reis \& Renzulli, 2021) since most talented youths experience role complexities in their lives. Talented youths mostly achieve the highest performance level in certain areas at a very young age (Scantlebury et al., 2020). Consequently, their routines are usually regulated under strict management for training time, travel time for competitions, and studies (Henriksen et al., 2020; Phibbs et al., 2018; Slaten et al., 2020). At the same time, they must learn how to deal with the stress they encounter in every tournament, organization, and in their personal life (Phibbs et al., 2018; Scantlebury et al., 2020; Slaten et al., 2020). All these factors certainly influence their academic achievement and peer relationships (Slaten et al., 2020). Thus, raising talented and/or gifted children may be more challenging than raising their peers (Rouquette, in press; Tessitore et al., 2021). The challenges faced by parents may significantly increase as these children demand the most extraordinary parenting requirements (Baimukanova, 2020; Tessitore et al., 2021).

The constituents of interconnected communities in the environment where parents are involved will give a unique meaning to their experiences (Clarke \& Harwood, 2014). This meaning 
can also affect the lives of the parents (Renati et al., 2017) and the parenting patterns. For example, the Javanese Muslim community believes that parenting aims to build the main character and fulfill children's rights. These characters include the character of being a good Muslim (possessing akhlakul kharimah - good behavior based on religion) (Karimah \& Ummah, 2020; Vinayastri, 2015) and the character of being a good Javanese person (Ali \& Arenggoasih, 2020). On the other hand, parents must also be responsible for fulfilling children's rights; therefore, Javanese Muslim parents expect their children's health from childhood (Ali \& Arenggoasih, 2020; Hartono et al., 2017). Accordingly, community, religiosity, and cultural features can be highly significant for exploring the challenges of parents in raising talented youths.

Most studies concerning talented youth have tended to explore parenting challenges from the western perspective (Baimukanova, 2020; Reis \& Renzulli, 2021; Tessitore et al., 2021; Wellisch, 2021). However, there is still no empirical research to describe the challenges from the perspective of Javanese Muslim parents. Therefore, the author proposes further research on the influence of Javanese Muslim social and cultural features, which are needed to improve theoretical understanding of parents' perceptions of the challenges in promoting the well-being of talented youth. Therefore, this study aimed to explore the challenges that parents experience in promoting the well-being of talented youths from the perspective of Javanese Muslim parents.

\section{Methods}

\subsection{Research design}

This study used a descriptive phenomenological approach to understand the essence of parents' challenges to promote the well-being of talented youth from the perspective of Javanese Muslim parents, which is still not clearly understood. Descriptive phenomena can describe the meaning of Javanese Muslim parents about parental challenges that they deal with.

\subsection{Setting and participants}

This study was conducted from August 2017 to April 2018. This study chose East Java and Central Java Provinces in Indonesia as the research location due to the fact that $98 \%$ of the Javanese population lives in these provinces, and around 80\% are Muslims. The participants of this study were 13 Javanese Muslim parents of talented youth, including three mothers and nine fathers. These participants were recruited based on the following criteria: (1) a mother or father who identified her/himself as a Javanese Muslim; (2) having talented children who had received any awards at least at the national level, and (3) able to communicate in both Indonesian and Javanese. Purposive and snowball techniques were used to select the participants.

\subsection{Data collection}

The principal researcher conducted all the interview processes. The researcher collected the data through semi-structured interviews and field notes. The interviews were conducted twice with each participant; the first and the second interviews were held on different days. During the first interview, the researcher asked several questions based on the interview guidelines. Several questions need to be investigated further to obtain the participants' answers eventually. The first interview session took 60 to 90 minutes. After making a verbatim transcript of the recording, the researcher read and reread the transcript. Then, the researcher identified the answers which required clarification through follow-up interviews at a later time. The principal researcher conducted the second interview to obtain additional data when the first interview required more in-depth data. The second interview lasted for approximately 30 to 45 minutes. All interviews were recorded using a voice recorder.

During the interviews, the researcher used mixed languages between Javanese and Indonesian. To open the interview process, the researcher used general introductory questions. An example of this question was: "Do you have any idea if your child is talented?." After the parents responded to the initial questions, the following interview aimed to clarify the initial responses, such as "What are the challenges as parents in raising your child?." This question aimed to explore parents further and to enable them to continue to talk about their experiences. Other questions, such as "How are the challenges affecting your daily life?" were designed to bring out the parental experience in detail.

While exploring the parents' experiences during the interviews, the researcher clarified some vague statements to ensure that the researcher's understanding of the experiences was consistent 
with how the parents experienced them. To gather further information, the researcher followed up using inquiry questions about the focused issues. During the interview process, the researcher also took field notes to improve the quality of the data.

\subsection{Data analysis}

Giorgi (2012) stated that researchers are trying to understand the meaning of the description as presented. However, before the process begins, descriptive phenomenology suggests that the researcher isolates his or her own parenting experience as it will influence the perception of the data during the data analysis process.

The researchers reread the transcribed text while listening to the audio recording to make sure the material was transcribed literally and accurately. After the researchers were sure that they had obtained a complete and accurate transcript, the raw data were analyzed in several steps, as illustrated. First, the researchers read the transcribed data several times to obtain an overall sense of the transcript being read. Second, the researchers identified the meaning unit. Third, the researchers converted meaning units into transformed unit meaning. The natural attitude of each parent was changed into phenomenological and psychologically sensitive expressions. Finally, the structure can be determined (Broome, 2011; Giorgi, 2012). The example in the data analysis process was provided in Table 1.

Table 1. Example in the data analysis process

\begin{tabular}{ll}
\hline \multicolumn{1}{c}{ Step and Transformation } & \multicolumn{1}{c}{ Statement } \\
\hline Transcription & $\begin{array}{l}\text { I am disappointed with her teachers'attitude. Some of them do not } \\
\text { support her talent. They asked why my daughter preferred taking } \\
\text { part in competitions to school activities. Sports cannot support her } \\
\text { future life. I do not understand her teachers' perception. They tend } \\
\text { to belittle her talent. They are not true teachers. }\end{array}$ \\
& $\begin{array}{l}\text { I am disappointed with the attitude of my daughter's teachers. They } \\
\text { tend to reject her talent. They are not real teachers. }\end{array}$ \\
Unit of meaning & $\begin{array}{l}\text { Parents are disappointed with teachers who do not support their } \\
\text { youth's talents. The teachers commented negatively on the athlete's }\end{array}$ \\
$\begin{array}{l}\text { Unit of transformation } \\
\text { meaning }\end{array}$ & $\begin{array}{l}\text { life. Parents think that teachers' attitudes of ignoring and/or even } \\
\text { belittling students' talents are not appropriate. }\end{array}$ \\
Sub-theme & Belittling attitudes from the teachers \\
Synthesis of the theme & Challenges from the community \\
structure &
\end{tabular}

\subsection{Trustworthiness}

The researchers used bracketing and reflection journaling during the research process. The researcher deliberately ignored all knowledge, opinions, or views concerning the researchers' background to minimize bias. Instead, the researcher locked all knowledge, beliefs, and thoughts about aspects that might influence the research process into a reflective journal. When the researchers reviewed the literature, the researchers focused on previous relevant research studies to find any knowledge gaps rather than to gather evidence that would probably influence the researchers' perceptions. The researchers then triangulated data from interviews and field notes to ensure the reliability and validity (rigor) of the research.

The researchers worked together to check whether the research process was acceptable, essentially regarding the research method, which included sampling selection, data collection, procedures, and data analysis. Then, the researchers assessed the internal consistency of whether the data supported the findings. The researchers also examined the consistency of the results, interpretations, and conclusions of the study. Furthermore, since this study was a part of a dissertation, the dissertation committee members reviewed and audited all research processes and findings. 


\subsection{Ethical considerations}

The institutional review board (IRB) of the Faculty of Nursing, Prince of Songkla University, Thailand, had approved this study (No. 2017 NSt-Qn 029). Informed consent was conveyed both orally and in written to the participants. This informed consent consisted of four important elements of ethical considerations, including the purpose of the study, what would happen during the interview, potential benefits, and any risks regarding the interview process. The researchers allowed parents to ask any questions related to the given informed consent and then let them decide whether to participate in the study or not.

\section{Results}

\subsection{Characteristics of participants}

The Javanese Muslim parents were recruited from two provinces in Indonesia: Central Java and East Java. Three mothers and nine fathers aged between 50 and 62 years participated in this study. Except for three parents (one was a housewife and the other two were retired), the rest were public servants or self-employed/entrepreneurs. Almost all of them completed their undergraduate education (6 Participants) or senior high school degree (5 Participants); the other two had finished elementary and junior high school. One participant was a widow, while the others were married (12 participants). Six Participants were included in middle-income, four in high-income, and the other three were categorized as low-income families. Demographic characteristics of participants were provided in Table 2.

Table 2. Demographic characteristics of the research participants $(n=13)$

\begin{tabular}{lc}
\hline Characteristics & Number of Parents \\
\hline Age (years old) & 5 \\
$40-55$ & 8 \\
$56-61$ & \\
Gender & 10 \\
Male & 3 \\
Female & 1 \\
Education Level & 1 \\
$\quad$ Elementary School & 5 \\
$\quad$ Junior High School & 6 \\
Senior High School & \\
Bachelor Degree & 12 \\
Marital Status & 1 \\
Married & \\
Widow & 3 \\
Economic Status & 6 \\
$\quad$ Low & 4 \\
Middle & \\
High & 5 \\
Occupation & 5 \\
Public servant & 2 \\
$\quad$ Entrepreneur/self-employee & 1 \\
$\quad$ Retired & \\
$\quad$ Housewife & \\
\hline
\end{tabular}

\subsection{Participants' perspectives in promoting the well-being of talented youths}

Based on the participants' perspectives, three themes were found: (1) Challenges coming from the youths, including the children's oppositional behavior and difficulties in managing children's activities, as students and as talented youths; (2) Community challenges were resulted from belittling attitudes from their children's teachers/lecturers, ridicule from their neighbors, genderbased discrimination, and lack of support from organizations; and (3) The existence of financial restrictions in the family.

\subsubsection{Challenges from the youths}

The participants stated that their main challenges were related to their children's oppositional behavior and difficulties in managing activities for the children with dual roles: as 
students and as talented youths. Parents described parenting youths as the most challenging parenting period because youths, during this age, tend to be in opposition to their parents. They reported that quarrels and strained relationships between parents and teens were common during this time. Moreover, breaking parental rules was a common problem for parents. For example, parents of youths with the talent of memorizing the Qur'an implemented some rules for their children. Their children were forbidden to watch television, listen to music, and sing songs. They believed that music and television materials could reduce the ability to memorize the Qur'an. However, the youths often broke these rules. They listened to music, sang songs, and watched television elsewhere, which could make their parents angry.

“...When my son sings songs, I am angry. They will find it difficult to memorize the Qur'an. They know it exactly (listening to music, singing songs, and watching television) are forbidden in our family. They often violate my rules. My son watches television at his friend's or relative's house. When I caught them, they argued me with some reasons..." (P11)

Other participants, whose children were youth athletes, stated that they experienced a strained relationship with their children. Young athletes often neglected training when they felt bored and stressed and needed to relax. Talented youths experienced social estrangement due to the lack of time they had. This causes them to become bored and stressed.

"Sometimes, he gets bored and stressed with training and needs to relax. I'm mad at him for not training. A table tennis athlete has to train regularly. This often strains our relationship..." (P1).

"Sometimes he misses regular training when she feels tired, bored and needs to relax. Her training center is located in another city; she has to go to the training center by train every Saturday morning and has to return to her hometown on Sunday evening. She rarely spends time with friends. Maybe, it causes her to become bored and stressed. She needs to relax." (P6)

According to parents, the main difficulty they experienced was how to manage the balance of the two main activities of university students, i.e., completing assignments from campus and participating in joint training schedules. As university students, the youths tended to pile the campus assignments on and completed them when the deadline for submitting the assignments was approaching. As a result, most of the campus assignments were eventually not completed by the required deadline. Parents complained that their teenagers did not have perseverance in doing their assignments. Even though they knew that unfinished tasks would affect the arranged schedule related to their athletic activities, reducing the time for training would decrease their physical stamina and lower the target set by the trainer.

“... As a university student, she should manage her campus assignments. Most of the courses she took have assignments with deadlines. However, she, again and again, delays doing the assignments. As a result, her assignments pile up. When the deadlines for the assignments come, she is often absent from training at the table tennis club. Because of this, she frequently doesn't achieve her training target." $\left(\mathrm{P}_{7}\right)$

"She has to finish her assignments before the deadline because she has a busy schedule as an athlete and as a university student. She sometimes misses them. She delays finishing her homework ...” (P4)

\subsubsection{Challenges from the community}

This theme refers to the attitudes and behaviors of teachers, neighbors, and/or sports/arts organizations that do not support talented youths and their families. The main source of these obstacles is the lecturers/teachers. One athlete's father complained about his son's bachelor thesis advisor, who often delayed meetings or rescheduled thesis consultation appointments. The parent felt that his son's advisor had a low commitment to support the talented youth. This resulted in 
their children having to extend the length of their studies. Accordingly, this caused parents to worry about their children's academic future.

"His advisor often reschedules thesis consultation appointments. She (advisor) did not have a good commitment to help my son. My son has trouble meeting his thesis advisor, so his study was extended. As a result, we had to reschedule some of the tournaments which he should have attended. We gave up on participating in some tournaments held in other provinces because he needed to consult his thesis with his advisor regularly. I'm afraid; if this continues, he might not be able to finish his study within this semester..." (P1)

Another parent was disappointed with teachers who did not support their youth's talents. The teachers commented negatively on the athlete's life. Parents thought that teachers' attitudes of ignoring and/or even belittling students' talents were not appropriate.

"I am disappointed with her teachers' attitudes. Some of them do not support her talent. They asked why my daughter preferred taking part in competitions to school activities. Sports cannot support her future life. I don't understand her teachers' perceptions. They tend to belittle her talent. They are not true teachers." (P6)

Another challenge that parents had was coming from their neighbors' comments. The neighbors would say that pursuing a career as an athlete leaves their life full of uncertainty in the future. The neighbors stated that because the talent was just a hobby, not a job. For example, the father of a female table tennis athlete $\left(\mathrm{P}_{7}\right)$ stated, "My neighbor said that all athletes face uncertain financial conditions in the future. Most of them become poor in their old age. They do not have enough money to live..." Such unsupportive comments make parents feel uncomfortable and disappointed. They find it difficult to stop the ridicule from some people in their social circle.

“...Why are they so unsympathetic? I feel uncomfortable and disappointed. My daughter just stays at home. She doesn't want to meet them (neighbors) and listen to their ridicule. It's hard to stop their comments..." (P13)

Gender-based discrimination is another challenge faced by parents of female athletes (soccer and Kempo athletes). In addition, some neighbors thought that some kinds of sports were considered inappropriate and incompatible or even violate the nature of a woman.

"My neighbors said that it (being a soccer player) is inappropriate for a woman; it's a men's sport." (P3).

"My schoolmates told me that joining Kempo made my daughter masculine.” (P10)

In addition, some people would consider it taboo if women traveled far from home alone even though they went abroad to bring the name of the nation to international events.

"My daughter often goes abroad to dance to bring the name of Indonesia. My neighbors asked me why I allowed my daughter to go abroad alone. They said she is a woman." (P8)

In addition, parents of young athletes perceived that the sports association which houses their children's talent did not adequately support their talent potential. They felt like the sports association was just exploiting them.

“The women's soccer organization never made a significant contribution to my daughter. They just want her achievements. They exploit her." (P3)

"He was ranked the first and was selected as the player to join the national team, but the lower-ranked player who had connections with the officials beat him. His friend did nepotism. The table tennis association couldn't do anything. The association official 
couldn't defend my son from being in the first team. I complained about it, but no one answered my protest." (P2)

\subsubsection{Financial constraints in the family}

The theme of financial constraints in the family refers to the financial pressure condition of the family that made it difficult for them to meet the needs of their children as students and talented youth. Parents often experienced financial constraints, especially the low and middleincome parents. All participants were from middle and low economic income classes. It was difficult for them to finance the needs of an athlete; besides, their children also did not receive scholarships for their undergoing education. This situation caused their children to be unable to focus on their studies or in competitions due to the lack of financial resources. Participants felt a heavy burden to meet the needs of athletes, such as sports equipment, sports clothing, club administration fees, competitions, and living costs to participate in competitions. Such types of expenses were very costly, which they frequently could not afford.

"We fight very hard. I buy everything I need for him. Most of the necessities are related to equipment, such as rackets, shoes, rubber, club administration fees, competitions and living expenses for competitions." (P1)

"As a public servant, my wife and I have a limited salary; it is even only to meet our daily needs; it is difficult." (P2)

"We have financial problems. Our business went bankrupt. We have no money at all. So, it put a tremendous amount of pressure on our family. As a result, we have difficulty paying for our children's education. She doesn't get any scholarships. We also have difficulty not only in education but also in preparing food." (P12)

\section{Discussion}

This study showed that parenting talented youths is the most challenging period since breaking parental rules at this age is a common problem that parents face. Talented youths often have asynchronous development, exhibit unusual behavior, have difficulty in accepting rules and routines, and have school problems, which cause frustration and increase parenting stress on parents (Renati et al., 2017). Also, this study identified difficulties faced by parents, mainly from father participants, to balance time management for their children that have dual roles of being a university student and for their talents' exercise. Fathers always try to meet the needs of their children and optimize their children's development (Khasanah \& Suratni, 2013), including making strict time management for their gifted children. This research also explains the reason for time management difficulty due to the habit of their children to procrastinate on completing campus assignments and prefer to do them when they are approaching deadlines, which has an impact on failure to complete assignments thoroughly. Consequently, they often forget the exercise and training that must be undertaken. These talented youths also experience social estrangement due to the lack of time they have. This causes them to become bored and stressed. Many causes of stress experienced by talented students include heavy workload, preparing for the future, academic responsibilities, extracurricular activities, and social life (Kregel, 2015). Commitment to training can also be a stressor for the youth when they want to spend quality time with friends (Elliott et al., 2018).

This study, however, identified that the low commitment and belittling behavior from lecturers/teachers in helping talented youth creates confusion for parents in managing the balance of roles played by their children. This makes parents worried about their children's academic future. The harmonious relationship between the lecturers and the students is an important aspect that contributes to the success of talented youths (Bonner, 2001). Previous studies identified that lecturers could cause stress for parents through their unsupportive behavior or statements regarding talent-related activities which their children need to attend (Bartley, 2014; Free, 2014; Geake \& Gross, 2008; Renati et al., 2017). Patronization, humiliation, and threats are some of the university/school stressors that can highly trigger the well-being of talented youth (Free, 2014). Lack of support from most lecturers for these youths and their families may be due to a lack of knowledge about talented people (Free, 2014). 
Moreover, this study also found that neighbors cause another stress felt by parents who have worked hard for the well-being of their talented youth. A previous study identified that one of the challenges that parents face stems from negative societal attitudes, i.e., stigmatization of talented youths who are seen as having poorer physical or mental health (Free, 2014). This study also shows similarities regarding the role of the community in increasing parental stress. That stigmatization is linked to academic achievement and anecdotally lower prospects in the future life of someone who chooses to pursue their talents over academics. The stigmatization has led some youths to stay at home instead of meeting neighbors after hearing their comments. In addition, parents and their talented youths often experience isolation (Renati et al., 2017).

Gender-based discrimination is another difficulty faced by parents of talented female youth. Parents admitted that some Javanese still believe in tasks difference based on gender. Khilmiyah (2017), in her study, found that usually, the community believes that women's duties include everything related to the use of tenderness and feelings; on the contrary, men's duties include everything related to physical and mental strength. In addition, there is a dichotomy of public and domestic roles rooted in the ideology that a woman's role is to be at home, and a man's role is to be the breadwinner (wage earner). In turn, this helps perpetuate the division between the productive and reproductive functions of men and women at home. Some Javanese people still think that the duties of Javanese women consist of make-up (macak), cooking (masak), and giving babies (manak) only (Tuapattinaya \& Hartati, 2014). Therefore, it is not surprising that parents also experience gender discrimination regarding the selection of their children's talents, especially parents whose daughters pursue sports that are predominantly done by males or are engaged in the male gender, such as Kempo, dominate, and soccer.

Some parents also voiced their dissatisfaction with the lack of support from the sports associations their children belong to. Being ignored by sports associations is an example of rejection from their talented youths. Renati et al. (2017) found that parents of talented youths perceive that the organization does not support them or their talented youths. However, a previous study reported that problems with organizations assisting talented youth are caused by some factors such as funds and personnel availability, spending on traveling competitions, and so on (Free, 2014).

This study states that some parents (middle and low-income families) face difficulties paying campus tuition and living expenses for students at university, meeting routine needs (e.g., equipment, membership fees) to support their children's talents, and participating in talent competitions held. These results confirm the previous research stating that parents of talented youth have to make adjustments and even sacrifice for their regular family routines. Supporting talented youths is expensive (Aujla et al., 2014).

\section{Implication and limitation}

This study provides several implications for nursing practices and nursing research. Understanding cultural and contextual experiences of Javanese Muslim parents with talented youth have implications for nursing practice that seeks to support parents to get through several challenges. Nurses can develop family-based programs by considering and incorporating holistic aspects into the program. In addition, this study also has implications for further research. The results of this study can be used as basic data in developing a parenting intervention model to improve the well-being of talented youths.

This study has limitations since the sampling selection used the snowball sampling method. Fathers as participants tended to direct the researchers to refer to the next participant of the same gender, i.e., male. Therefore, the majority of participants in this study were fathers. In addition, the selection of talented youths by using the snowball method has limited the selection of talents possessed by the youths. In this study, the majority of talented youth are in the sports field.

\section{Conclusion}

This study identified the real challenges faced by talented youths' parents, including the challenges coming from the youths, the community, and family financial constraints that affected the lives of parents. Nurses should be aware of and develop family-based programs to support parents in promoting the well-being of talented youths by considering holistic aspects in making their interventions. 


\section{Acknowledgment}

The authors gratefully thank all parents who participated in this study. We also thank the Directorate General of Higher Education, Ministry of Research and Technology, the Republic of Indonesia, for the financial support of this research.

\section{Author contribution}

NSD: study design, conceptualization, data collection, data analysis, manuscript writing; PJ: study design, manuscript writing; WW: study design, data analysis, manuscript writing.

\section{Conflict of interest}

The authors declare that there is not any conflict of interest.

\section{References}

Ali, M., \& Arenggoasih, W. (2020). Communication of Javanese family beyond phenomenology religious life, ethics and human dignity. Easychair, 2516-2314, https://easychair.org/publications/preprint_open/Trsr

Aujla, I. J., Nordin-Bates, S., \& Redding, E. (2014). A qualitative investigation of commitment to dance: Findings from the UK centres for advanced training. Research in Dance Education, 15(2), 138-16o. https://doi.org/10.1080/14647893.2013.825764

Baimukanova, R. (2020). Parenting gifted and talented youths: Challenges parents have and their role in children's academic performance. [Master's Thesis, Nazarbayev University]. Nazarbayev University Repository. https://nur.nu.edu.kz/bitstream/handle/123456789/ 4831/MSc_2020_Raikhan \%20Baimukanova.pdf?sequence=1\&isAllowed=y

Bartley, V. (2014). Educators' attitudes towards gifted students and their education in a regional Queensland school. Talent Education, 28(1/2), 24-31.

Bonner, F. A. (2001). Gifted African American male college students: A phenomenological study. National Research Center on the Gifted and Talented. https://files.eric.ed.gov/ fulltext/ED459558.pdf

Broome, R. E. (2011). Descriptive phenomenological psychological method: An example of a methodology section from doctoral dissertation. [Dissertation, Saybrook University]. Semantic scholar. http://www.phenomenologyblog.com/wp-content/ uploads/2012/04/ Broome-2011-Phenomenological-Psychological-Dissertation-Method-Chapter.pdf

Clarke, N. J., \& Harwood, C. G. (2014). Parenting experiences in elite youth football: A phenomenological study. Psychology of Sport and Exercise, 15(5), 528-537. https://doi.org/10.1016/ j.psychsport.2014.05.004

Dewi, N. S., Jittanoon, P., \& Wiroonpanich, W. (2021). Understanding the meaning of talented youth well-being by Javanese muslim parents. Songklanagarind Journal of Nursing, 41(1), 24-36.

Elliott, S., Drummond, M. J. N., \& Knight, C. (2018). The experiences of being a talented youth athlete: Lessons for parents. Journal of Applied Sport Psychology, 30(4), 437-455. https://doi.org/10.1080/10413200.2017.1382019

Free, S. A. (2014). Support for parents of gifted and talented youths in the western region of Melbourne. [Dissertation, College of Arts Victoria University]. Victoria University Repository. http://vuir.vu.edu.au/id/eprint/ 28811

Geake, J. G., \& Gross, M. U. (2008). Teachers' negative affect toward academically gifted students: An evolutionary psychological study. Gifted Child Quarterly, 52(3), 217-231. https://doi.org/10.1177/0016986208319704

Giorgi, A. (2012). The descriptive phenomenological psychological method. Journal of Phenomenological Psychology, 43(1), 3-12. https://doi.org/10.1163/156916212X632934

Hartono, H. S., Davies, S. G., \& MacRae, G. (2017). 'You can't avoid sex and cigarettes': How Indonesian Muslim mothers teach their children to read billboards. Pacific Journalism Review, 23(2), 179-196. https://search.informit.org/doi/10.3316/informit.2320105161425 69 
Henriksen, K., Schinke, R., McCann, S., Durand-Bush, N., Moesch, K., Parham, W. D., Larsen, C. H., Cogan, K., Donaldson, A., \& Poczwardowski, A. (2020). Athlete mental health in the olympic/paralympic quadrennium: A multi-societal consensus statement. International Journal of Sport and Exercise Psychology, 18(3), 391-408. https://doi.org/10.1080/1612197X.2020. 1746379

Janah, E. N., Andriany, M., \& Dewi, N. S. (2018, November 17). Permasalahan subjektif wellbeing pada remaja berbakat di Indonesia: Literature review [The subjectives well-being problems among talented youth in Indonesia: A literature review] [Conference presentation]. Seminar Nasional Keperawatan, Semarang, Indonesia.

Karimah, K., \& Ummah, S. S. (2020). Prophetic parenting dalam membentuk akhlak Islami anak usia dini pada Himpunan Wali Santri (HIWASI) RA Al Mansur Bulangan Haji Kecamatan Pegantenan Kabupaten Pamekasan [The role of prophetic parenting to develop preschool children's Islamic morals in the Association of Santri Guardians (HIWASI) RA Al Mansur Bulangan Haji Pegantenan sub-district Pamekasan regency]. Kiddo: Jurnal Pendidikan Islam Anak Usia Dini, 1(2), 134-146. https://doi.org/10.19105/kiddo.v1i2. 3686

Khasanah, U., \& Suratni, S. (2013). Healthy parenting skills program toward first-time father's skills on caring for newborn baby. Nurse Media Journal of Nursing, 3(2), 581-590. https://doi.org/10.14710/nmjn.v3i2.600o

Khilmiyah, A. (2017). Stres kerja guru perempuan di Kecamatan Kasihan Bantul Yogyakarta [The job stress of female teachers in Kasihan sub-district Bantul Yogyakarta]. Lentera Pendidikan: Jurnal Ilmu Tarbiyah dan Keguruan, 15(2), 135-143.

Kregel, E. A. (2015). Addressing the social, emotional, and academic needs of gifted high school students. [Dissertation, The University of Toledo]. Ohio. https://etd.ohiolink.edu/ apexprod/rws_etd/send_file/send?accession=toledo1438706219\&disposition=inline

Phibbs, P. J., Jones, B., Roe, G., Read, D., Darrall-Jones, J., Weakley, J., Rock, A., \& Till, K. (2018). The organised chaos of English adolescent rugby union: Influence of weekly match frequency on the variability of match and training loads. European Journal of Sport Science, 18(3), 341348. https://doi.org/10.1080/17461391.2017.1418026

Reis, S. M., \& Renzulli, S. J. (2021). Parenting for strengths: Embracing the challenges of raising children identified as twice exceptional. Gifted Education International, 37(1), 41-53. https://doi.org/10.1177/0261429420934435.

Renati, R., Bonfiglio, N. S., \& Pfeiffer, S. (2017). Challenges raising a gifted child: Stress and resilience factors within the family. Gifted Education International, 33(2), 145-162. https://doi.org/10.1177/0261429416650948

Rouquette, O., Knight, C., Lovett, V., \& Heuzé, J.P. (in press). Parent-athlete relationships: A central but underexamined consideration within sport psychology. Sport and Exercise Psychology Review.

Scantlebury, S., Till, K., Sawczuk, T., Phibbs, P., \& Jones, B. (2020). Navigating the complex pathway of youth athletic development: Challenges and solutions to managing the training load of youth team sport athletes. Strength \& Conditioning Journal, 42(6), 100-108. https://doi.org/10.1519/SSC.0000000000000564

Slaten, C. D., Ferguson, J. K., Hughes, H. A., \& Scalise, D. A. (2020). 'Some people treat you like an alien': Understanding the female athlete experience of belonging on campus. The Educational and Developmental Psychologist, 37(1), 11-19. https://doi.org/10.1017/edp. 2020.5

Tessitore, A., Capranica, L., Pesce, C., De Bois, N., Gjaka, M., Warrington, G., Mac Donncha, C., \& Doupona, M. (2021). Parents about parenting dual career athletes: A systematic literature review. Psychology of Sport and Exercise, 53,1-10. https://doi.org/10.1016/ j.psychsport.

Tuapattinaya, Y. I. F., \& Hartati, S. (2014). Pengambilan keputusan untuk menikah beda etnis: Studi fenomenologis pada perempuan Jawa [Decision making to marriage among different ethnics people: A phenomenological study on Javanese women]. Jurnal Psikologi, 13(1), 3441. https://doi.org/10.14710/jpu.13.1.34-41 
Vinayastri, A. (2015). Pengaruh pola asuh (parenting) orang-tua terhadap perkembangan otak anak usia dini [The effect of parenting on the brain development of early childhood]. Jurnal Ilmiah WIDYA, 3(1), 33-42.

Wellisch, M. (2021). Parenting with eyes wide open: Young gifted children, early entry and social isolation. Gifted Education International, 37(1), 3-21. https://doi.org/10.1177/ 0261429419899946. 